\title{
Editorial \\ El aprendizaje basado en problemas
}

\author{
Fabio Alberto Garzón Díaz, Ph.D. \\ Fecha de publicacion en línea: 18 de mayo de 2017 \\ DOI: http://dx.doi.org/10.18359/reds.2897
}

\begin{abstract}
A pesar de los esfuerzos que han realizado las universidades e instituciones gubernamentales y no gubernamentales en América Latina para incentivar a los estudiantes a continuar la educación superior, algunos estudios coinciden en que los principales motivos de la deserción son los altos costos de las matriculas, la necesidad de trabajar para el mantenimiento de los propios estudiantes, la falta de preparación con la que salen de los colegios y problemas familiares, entre otros. Estoy convencido de que existe otro factor que afecta directamente la deserción y por consiguiente a la calidad de la educación, y es la falta de implementación de modelos pedagógicos institucionales que estén acordes con el mundo globalizado.
\end{abstract}

Los modelos pedagógicos de la Educación Superior en Colombia y de muchas universidades de Latinoamérica y el Caribe son obsoletos y funcionan desligados de la realidad del mundo contemporáneo. Un ejemplo típico de esta situación es la enseñanza-aprendizaje de la ética-bioética en los programas académicos de los diferentes programas. La enseñanza de la bioética en programas como las ingenierías o ciencias de la salud está reducida a una sola asignatura totalmente descontextualizada y sin ningún hilo conductor con el resto del plan de estudio, y mucho menos con la realidad que va a enfrentar el estudiante una vez culmine sus estudios.

Este problemática ha sido tema de muchos debates a nivel nacional e internacional; cabe destacar dos documentos importantes: la Declaración de Bolonia (Documento Magna Charta Universitatum) y la Declaración Mundial sobre la Educación Superior en el Siglo XXI (Declaración Mundial sobre la Educación Superior en el Siglo XXI). En Bolonia, Italia (donde surgió la universidad, segunda institución más antigua del mundo occidental, después de la Iglesia católico-romana), en 1986

8 comenzo a gestarse la idea de un movimiento que buscaba una generación de alianzas académicas entre las universidades de este continente. Dos años más tarde, en 1988, se produjo el relanzamiento de la educación superior europea, con la firma de la Magna Charta Universitatum por parte de los rectores de todas 
las universidades de 30 Estados del continente, en ocasión del cumplimiento del aniversario 900 de la fundación de la Universidad de Bolonia.

El documento final expuso lo que se denomino principios fundamentales, algo asi como los cimientos sobre los cuales se debía soportar y sustentar el quehacer de la institución universitaria en Europa en el presente y en el futuro:

1) La universidad, en el seno de sociedades organizadas de forma diversa debido a las condiciones geográficas y a la influencia de la historia, es una institución autónoma que, de manera crítica, produce y transmite la cultura por medio de la investigación y de la enseñanza. Abrirse a las necesidades del mundo contemporáneo exige disponer, para su esfuerzo docente e investigador, de una independencia moral y científica frente cualquier poder político, económico e ideológico.

2) En las universidades, la actividad docente es indisociable de la actividad investigadora, a fin de que la enseñanza sea igualmente capaz de seguir la evolución, tanto de las necesidades y de las exigencias de la sociedad como de los conocimientos científicos.

3) Siendo la libertad de investigación, de enseñanza y de formación el principio básico de la vida de las universidades, tanto los poderes públicos como las universidades, cada uno en sus respectivos ámbitos de competencia, deben garantizar y promover el respeto a esta exigencia fundamental. Con el rechazo de la intolerancia y mediante el diálogo permanente, la universidad es un lugar de encuentro privilegiado entre profesores - que disponen de la capacidad de transmitir el saber y los medios para desarrollarlo a través de la investigación y de la innovación-y estudiantes — que tienen el derecho, la voluntad y la capacidad de enriquecerse con ello-.

4) La universidad, depositaria de la tradición del humanismo europeo, pero con la constante preocupación de alcanzar el saber universal, ignora toda frontera geográfica o política para asumir su misión y afirma la imperiosa necesidad del conocimiento recíproco y de la interacción de las culturas (Documento Magna Charta Universitatum).

Para darle vida a estos principios fundamentales, la Magna Charta Universitatum expuso igual número de caminos por seguir, a los que denominó medios.

1) A fin de preservar la libertad de investigación y de enseñanza, deben facilitarse al conjunto de los miembros de la comunidad universitaria los instrumentos adecuados para su realización. 
2) La selección de los profesores, asi como la reglamentación de su estatuto, debe regirse por el principio de la indisociabilidad entre la actividad investigadora y la actividad docente.

3) Respetando la especificidad de su situación, cada universidad debe garantizar a los estudiantes la salvaguarda de las libertades, asi como las condiciones necesarias para alcanzar sus objetivos en materia de cultura y de formación.

4) Las universidades - especialmente las europeas - consideran el intercambio recíproco de información y de documentación y la multiplicación de iniciativas comunes, como instrumentos fundamentales para el progreso continuado de conocimientos" (Documento Magna Charta Universitatum).

En septiembre de 2008, en la celebración del aniversario 920 de la fundación de la Universidad de Bolonia, el veinteavo de la firma de la Magna Charta Universitatum y los nueve de la Declaración de Bolonia, los rectores de las universidades europeas se reunieron con el fin de hacer balances de los resultados alcanzados hasta el presente. A este encuentro fueron invitados los rectores de instituciones de educación superior de países de los otros cuatro continentes, incluyendo América Latina. Un representante por cada región hizo un recuento de los principales beneficios que esta declaración trajo a Europa y al resto del mundo. En representación de América Latina, el conferencista fue el químico Moisés Wasserman Lerner, exrector de la Universidad Nacional de Colombia.

Por otro lado, del 5 al 9 de octubre de 1998 se reunieron en la sede de la Unesco en París importantes académicos de todo el mundo participantes en la Conferencia Mundial sobre la Educación Superior, y aprobaron la Declaración Mundial sobre Educación Superior en el siglo XXI: visión y acción; y el marco de acción prioritaria para el cambio y el desarrollo de la educación superior. El preámbulo de la declaración argumenta:

La educación superior se enfrenta en todas partes a desafíos y dificultades relativos a la financiación, la igualdad de condiciones de acceso a los estudios y en el transcurso de los mismos, una mejor capacitación del personal, la formación basada en las competencias, la mejora y conservación de la calidad 10 de la enseñanza, la investigación y los servicios, la pertinencia de los planes miento de acuerdos de cooperación eficaces y la igualdad de acceso a los beneficios que reporta la cooperación internacional. La educación superior 
debe hacer frente a la vez a los retos que suponen las nuevas oportunidades que abren las tecnologías, que mejoran la manera de producir, organizar, difundir y controlar el saber y de acceder al mismo. Deberá garantizarse un acceso equitativo a estas tecnologías en todos los niveles de los sistemas de enseñanza. (Declaración Mundial sobre la Educación Superior en el Siglo XXI)

Ambos documentos han provocado el inicio de un proceso reflexión sobre la calidad de la docencia universitaria y la necesidad de cambios importantes en los modos convencionales de enseñanza. Asi , los investigadores de la Facultad de Educación y Humanidades de la Universidad Militar Nueva Granada vienen analizando un nuevo modelo pedagógico universitario llamado aprendizaje basado en problemas (ABP), por cuanto pueda ayudar a las instituciones de educación Superior a afrontar los retos que plantea el mundo globalizado (Felder y Brent, 2003).

El aprendizaje basado en problemas (ABP) se perfila como uno de los enfoques pedagógicos más innovadores en la formación profesional y académica actual, conquistando cada vez más espacios en las principales universidades del mundo, ente las cuales se puede resaltar la Universidad de McMaster, en Canada , la Universidad de Maastricht, en Holanda; la Universidad de Quebec, en Canada ; la Escuela de Medicina, de Harvard; la Universidad Autónoma de México (UNAM); la Universidad de Sao Paulo, en Brasil. También este enfoque pedagógico llegó con fuerza a España liderado por la Universitat Autonoma de Barcelona, la Escuela Universitaria d Infermeria Vall d Hebron, la Universitat Pompeu Fabra, la Universidad Autónoma de Madrid y la Universidad de Valladolid.

Tras este movimiento se encuentra la búsqueda de nuevos modelos de producción y organización del conocimiento, de acuerdo con las demandas y necesidades de las sociedades contemporáneas, asi como a la denominada sociedad del conocimiento (Amaya, 2000; Van Berkel y Schmidt, 2001; Woods, 1996). La universidad tradicional, la cual segmentaba el conocimiento en áreas, disciplinas y asignaturas, ya no satisface las necesidades de la adecuación del conocimiento en nuevas redes e interfaces. Los estudios universitarios requieren la elaboración depurada de síntesis complejas, con aportación de distintas fuentes de información para alcanzar un pleno análisis y desarrollo de los nuevos cursos e investigaciones científicas. Frente a este panorama complejo y multifacético e interdisciplinario, está claro que los cambios son fundamentales para consolidar el papel de la universidad en la sociedad contemporánea y permitir la aplicación de las recomendaciones realizadas por los documentos internacionales y declaraciones sobre la educación superior, y así 
fortalecer esta tendencia y provocar cambios en los sistemas de educación ya instalados (Perkins, 1998).

Ahora les corresponde a las universidades latinoamericanas pensar la Magna Charta Universitatum y la Declaración Mundial sobre la Educación Superior en el Siglo XXI. Algunos rectores de universidades latinoamericanas y del Caribe que firmaron simbólicamente la Declaración de Bolonia (entre estos el rector de nuestra Universidad) se comprometieron a trabajar fuertemente en la calidad de la educación que permita gran intercambio y fluidez, y que tenga una fuerte presencia internacional. De esto dependerá, en gran medida, la forma como se pueda evolucionar en la educación superior.

El reto no es nada fácil para estos países con gran nivel de pobreza y analfabetismo, y sobre todo con muy frágiles sistemas de democracia; sin embargo, esperamos que como consecuencia de las declaraciones de este tipo de encuentros se produzcan acciones o políticas concretas que contribuyan al progreso de la institución universitaria y de la educación, y que no simplemente se quede en el entusiasmo pasajero de los participantes y en la proclama de una serie de propósitos que se esfuman con el paso del viento y del tiempo.

Nuestro aporte para lograr este cambio educativo consiste en proponer el aprendizaje basado en problemas como una poderosa herramienta pedagógica para la formación de profesionales, científicos de nuestras universidades latinoamericanas, en sociedades que exigen la estructuración de conocimientos sólidos y profundos de la realidad con vistas a la innovación, la transformación de la realidad y la construcción de la justicia social.

\section{Referencias}

Amaya, A. (2000) La clase magistral, paradigma de una enseñanza eficaz. En: enseñabilidad de los saberes. Memorias sobre actualización y mejoramiento curricular. Bogotá: Editorial Universidad de la Sabana.

Cooney, T. (2002). Introduction. En J. Cusick (Ed.), Innovative Techniques for LargeGroups Instruction (pp. 135-145). Arlington: National Science Teachers Association

Declaración Mundial sobre la Educación Superior en el Siglo XXI: visión y acción. Recuperado el 28 de mayo de 2017, de http://www.unesco.org/education/educprog/

12 wche/declaration_spa.htm

Documento Magna Charta Universitatum (s. f.). Recuperado el 28 de mayo de 2017, de http://www.magna-charta.org/magna.htm 
Felder, R.M. y Brent, R. (2003). Learning by Doing. Chemical Engineering Education, 37(4), 282-283.

Perkins, D. (1998). What is Understanding? En M.S. Wiske (Ed), Teaching for Understanding. Linking Research with Practice. San Francisco: Jossey-Bass Publishers.

Van Berkel, H.J.M. y Schmidt, H.G. (2001). The Role of Lectures in Problem-Based Learning. Annual Meeting of the American Educational Research Association. Seattle.

Woods, D.R. (1996). Problem-Based Learning: Helping Your Students Gain the Most from PBL. Hamilton: Seldon Griffin Graphics. 


\title{
Editorial
}

\section{Problem-based learning}

\author{
Fabio Alberto Garzón Díaz, Ph.D. \\ Fecha de publicacion en linea: 18 de mayo de 2017 \\ DOI: http://dx.doi.org/10.18359/reds. 2897
}

\begin{abstract}
Despite the efforts made by universities and governmental and non-governmental institutions in Latin America to encourage students to continue higher education, some studies agree that the main reasons for dropping out are the high costs of enrollment, Need to work for the maintenance of the students themselves, lack of preparation with which they leave the schools and family problems, among others. I am convinced that there is another factor directly affecting desertion and therefore the quality of education, and it is the lack of implementation of institutional teaching models that are in keeping with the globalized world.
\end{abstract}

The teaching models of Higher Education in Colombia and of many universities in Latin America and the Caribbean are obsolete and function disconnected from the reality of the contemporary world. A typical example of this situation is the teaching-learning of ethics-bioethics in the academic programs of the different programs. The teaching of bioethics in programs such as engineering or health sciences is reduced to a single subject decontextualized and without any guiding thread with the rest of the study plan, much less with the reality that will face the student once complete his studies.

This issue has been the subject of many debates at national and international levels; two important documents are the Bologna Declaration (Magna Charta Universitatum) and the World Declaration on Higher Education for the Twenty-First Century (World Declaration on Higher Education for the Twenty-First Century). In Bologna, Italy (where the university emerged, the second oldest institution in the Western world after the Roman Catholic Church), in 1986 the idea of a movement that sought a generation of academic alliances among the universities of this continent began to take shape. Two years later, in 1988, there was a relaunch 14 of European higher education, with the signature of the Magna Charta Universitatum by the rectors of all universities in 30 states of the continent, on the occasion of the 900th anniversary of the Founding of the University of Bologna. 
The final document exposed what were called fundamental principles, something like the foundations on which the work of the university institution in Europe in the present and the future should be supported and sustained:

1) The University, in societies organized differently due to geographical conditions and the influence of history, is an autonomous institution that critically produces and transmits culture through research and teaching. To be open to the needs of the contemporary world demands, for its educational and research effort, a moral and scientific independence against any political, economic and ideological power.

2) In universities, teaching activity is inseparable from research activity, so that education is equally capable of following the evolution of both the needs and demands of society and scientific knowledge.

3) Since freedom of research, education, and training are the primary principle of the life of universities, both public authorities and universities, each in their respective fields of competence, must guarantee and promote respect for this fundamental requirement. With the rejection of intolerance and through permanent dialogue, the university is a privileged meeting place for teachers-who have the capacity to transmit knowledge and the means to develop it through research and innovation-and students-which have the right, the will and the ability to enrich themselves with it.

4) The university, which is the depository of the tradition of European humanism, but with the constant concern to achieve universal knowledge, ignores any geographical or political frontier to assume its mission and affir$\mathrm{ms}$ the imperative need of reciprocal knowledge and interaction of cultures (Document Magna Charta Universitatum).

To give life to these fundamental principles, the Magna Charta Universitatum exposed the same number of paths to follow, which it called means.

1) To preserve freedom in research and teaching, the instruments appropriate to realize that freedom must be made available to all members of the University community.

2) Recruitment of teachers, and regulation of their status, must obey the principle that research is inseparable from teaching.

3) Each university must -with due allowance for particular circumstances- ensure that its students' freedoms are safeguarded, and that they enjoy 
concessions in which they can acquire the culture and training which it is their purpose to possess.

4) Universities -particularly in Europe- regard the mutual exchange of information and documentation, and frequent joint projects for the advancement of learning, as essential to the steady progress of knowledge. (Document Magna Charta Universitatum).

In September 2008, in the celebration of the 920th anniversary of the founding of the University of Bologna, the twentieth of the signature of the Magna Charta Universitatum and the ninth of the Bologna Declaration, the rectors of the European universities met for the purpose of make balances of the results achieved until the present. To this meeting were invited the rectors of institutions of higher education from countries of the other four continents, including Latin America. One representative for each region recounted the main benefits that this statement brought to Europe and the rest of the world. Representing Latin America, the lecturer was the chemist Moisés Wasserman Lerner, ex-rector of the National University of Colombia.

On the other hand, from 5th to 9th October 1998, prominent academics from around the world who took part in the World Conference on Higher Education met at Unesco's headquarters in Paris and approved the World Declaration on Higher Education for the Twenty-First Century: Vision and Action; and the framework for priority action for the change and the development of higher education. The preamble to the statement argues:

Everywhere higher education is faced with great challenges and difficulties related to financing, equity of conditions at access into and during the course of studies, improved staff development, skills-based training, enhancement and preservation of quality in teaching, research and services, relevance of programmes, employability of graduates, establishment of efficient co-operation agreements and equitable access to the benefits of international co-operation. At the same time, higher education is being challenged by new opportunities relating to technologies that are improving the ways in which knowledge can be produced, managed, disseminated, accessed and controlled. Equitable access to these technologies should be ensured at all levels of education systems. (World Declaration on Higher Education for the Twenty-First Century)

Both documents have triggered a process of reflection on the quality of university teaching and the need for major changes in conventional modes of teaching. Thus, researchers from the Faculty of Education and Humanities of the Universidad 
Militar Nueva Granada are analyzing a new university pedagogical model called problem-based learning (PBL), because it can help higher education institutions to face the challenges posed by the globalized world (Felder and Brent, 2003).

Problem-based learning (PBL) is emerging as one of the most innovative pedagogical approaches in today's professional and academic training, conquering more and more spaces in the main universities of the world, which can be highlighted McMaster University in Canada; The University of Maastricht in the Netherlands; The University of Quebec in Canada; Harvard Medical School; The Autonomous University of Mexico (UNAM); The University of Sao Paulo, in Brazil. Also, this pedagogical approach arrived with force to Spain led by Universitat Autonoma of Barcelona, University School d Infermeria Vall d Hebron, Universitat Pompeu Fabra, Autonomous University of Madrid and the University of Valladolid.

Following this movement is the search for new models of production and organization of knowledge, according to the demands and needs of contemporary societies, as well as the so-called society of knowledge (Amaya, 2000; Van Berkel and Schmidt, 2001; Woods, 1996). The traditional university, which segmented knowledge into areas, disciplines, and subjects, no longer meets the needs of the adequacy of knowledge in new networks and interfaces. The university studies require the elaboration of complex syntheses, with the contribution of different sources of information to reach a full analysis and development of the new courses and scientific investigations. Faced with this complex and multifaceted and interdisciplinary panorama, it is clear that the changes are fundamental to consolidate the role of the university in contemporary society and allow the application of the recommendations made by international documents and statements on higher education, and thus strengthen This trend and bring about changes in the education systems already in place (Perkins, 1998).

It is now up to Latin American universities to think about the Magna Charta Universitatum and the World Declaration on Higher Education for the Twenty-First Century. Some rectors from Latin American and Caribbean universities who symbolically signed the Bologna Declaration (among them the rector of our University) pledged to work hard on the quality of education that allows great exchange and fluency and has a strong international presence. This will depend, to a large extent, on the way in which higher education can evolve.

The challenge is not easy for these countries with a high level of poverty and illiteracy, and especially with very fragile systems of democracy; However, we hope that as a consequence of the declarations of this type of meetings, concrete 
actions or policies will be produced that will contribute to the progress of the university institution and education, and that not only stay in the passing enthusiasm of the participants and in the Proclaims a series of purposes that vanish with the passage of wind and time.

Our contribution to achieving this educational change is to propose problem-based learning as a powerful pedagogical tool for the training of professionals, scientists from our Latin American universities, in societies that demand the structuring of solid and profound knowledge of reality with a view to Innovation, the transformation of reality and the construction of social justice.

\section{References}

Amaya, A. (2000). La clase magistral, paradigma de una enseñanza eficaz. En: enseñabilidad de los saberes.

Cooney, T. (2002). Introduction. En J. Cusick (Ed.), Innovative Techniques for Large-Groups Instruction (pp. 135-145). Arlington: National Science Teachers Association

Declaración Mundial sobre la Educación Superior en el Siglo XXI: visión y acción. Recuperado el 28 de mayo de 2017, de http://www.unesco.org/education/educprog/ wche/declaration_spa.htm

Documento Magna Charta Universitatum (s. f.). Recuperado el 28 de mayo de 2017, de http://www.magna-charta.org/magna.htm

Felder, R.M. y Brent, R. (2003). Learning by Doing. Chemical Engineering Education, 37(4), 282-283.

Perkins, D. (1998). What is Understanding? En M.S. Wiske (Ed), Teaching for Understanding. Linking Research with Practice. San Francisco: Jossey-Bass Publishers.

Van Berkel, H.J.M. y Schmidt, H.G. (2001). The Role of Lectures in Problem-Based Learning. Annual Meeting of the American Educational Research Association. Seattle.

Woods, D.R. (1996). Problem-Based Learning: Helping Your Students Gain the Most from PBL. Hamilton: Seldon Griffin Graphics. 


\title{
Editorial
}

\section{A aprendizagem baseada em problemas}

\author{
Fabio Alberto Garzón Díaz, Ph.D. \\ Fecha de publicacion en linea: 18 de mayo de 2017 \\ DOI: http://dx.doi.org/10.18359/reds. 2897
}

\begin{abstract}
Apesar dos esforços que tem desenvolvido as universidades e instituições governamentais e não governamentais na América Latina para encorajar a os estudantes a prosseguir o ensino superior, yalguns estudos concordam em que as principais razões para a deserção são os altos custos das inscrições, a necessidade de trabalhar para manter-se assim mesmos, a falta de preparação com que deixam as escolas e problemas familiares, entre outros. Estou convencido de que há outro fator que afeta diretamente a deserção e, portanto, a qualidade da educação, e falta de implementação de modelos pedagógicos institucionais que sejam consistentes com o mundo globalizado.
\end{abstract}

Os modelos pedagógicos do Ensino Superior na Colômbia e de muitas universidades da América Latina e do Caribe são obsoletos e funcionam separados da realidade do mundo contemporâneo. Um exemplo típico desta situação é o ensino-aprendizagem da ética-bioética nos programas acadêmicos dos diferentes programas. O ensino da bioética em programas como as engenharias ou ciências da saúde é reduzido a uma única disciplina totalmente dês contextualizada e sem fio condutor com o resto do currículo, e muito menos com a realidade que irá enfrentar o estudante uma vez concluía seus estudos.

Esta questão tem sido objeto de muitos debates a nível nacional e internacional; cabe ressaltar dois importantes documentos: a Declaração de Bolonha (Documento Magna Charta Universitatum) e a Declaração Mundial sobre a Educação Superior no Século XXI (Declaração Mundial sobre Educação Superior no Século XXI). Em Bolonha, Itália (onde emergiu a universidade segunda instituição mais antiga do mundo ocidental, depois da Igreja católica-romana), em 1986, começou a desenvolver-se a ideia de um movimento que buscava uma geração de parcerias acadêmicas entre as universidades deste continente. Dois anos depois, em 1988, se produze o relançamento do ensino superior europeu, com a assinatura da Magna Charta Universitatum pelos reitores de todas as universidades em 30 Estados do continente, por ocasião do cumprimento do aniversário 900 da fundação da Universidade de Bolonha. 
O documento final expos o que foi denominado princípios fundamentais, algo assim como os alicerces sobre os quais se devia apoiar e sustentar o trabalho da instituição universitária na Europa no presente e no futuro:

1) A universidade, no seio de sociedades organizadas de diversas formas, devido às condições geográficas e a influência da história, é uma instituição autônoma que, de forma crítica, produz e transmite a cultura através da pesquisa e do ensino. Abrir-se às necessidades do mundo contemporâneo exige dispor, para seu esforço do ensino e de pesquisa, de uma independência moral e científica frente a qualquer poder político, econômico e ideológico.

2) Nas universidades, a atividade docente é inseparável da atividade de pesquisa, de modo que o ensino também seja igualmente capaz de acompanhar a evolução tanto das necessidades e das demandas da sociedade como dos conhecimentos científicos.

3) Sendo a liberdade de pesquisa, de ensino e de formação o princípio básico da vida das universidades, tanto os poderes públicos como as universidades, cada um em suas respectivas áreas de competência, devem garantir e promover o respeito a este requisito fundamental. Com a rejeição da intolerância e através do diálogo permanente, a universidade é um lugar de encontro privilegiado entre os professores,-que têm a capacidade de transmitir o conhecimento e os meios para desenvolvê-lo através da investigação e à inovação- e estudantes-que têm o direito, à vontade e a capacidade de enriquecer-se com isso-.

4) A universidade, depositária da tradição do humanismo europeia, mas com o cuidado constante de alcançar o conhecimento universal, ignora toda fronteira geográfica ou política para assumir a sua missão e afirma a necessidade vital do conhecimento mútuo e da interação das culturas (Documento Magna Charta Universitatum).

Para dar vida a estes princípios fundamentais, a Magna Charta Universitatum exibiu igual número de caminhos a seguir, aos quais que ele chamou de meios.

1) A fim de preservar a liberdade de pesquisa e de ensino deve ser fornecido a todos os membros da comunidade universitária as ferramentas apropriadas para a sua realização.

20 2) A seleção dos professores assim como a regulamentação do seu estatuto, deve ser regida pelo princípio da indivisibilidade entre a atividade de pesquisa e a atividade de ensino. 
3) Respeitando a especificidade de sua situação, cada universidade deve garantir aos estudantes a salvaguarda das liberdades, bem como as condições necessárias para atingir os seus objetivos em matéria de cultura e de formação.

4) As universidades —especialmente as europeias— consideram o intercâmbio recíproco de informação e de documentação e a multiplicação de iniciativas comuns, como instrumentos fundamentais para o contínuo progresso de conhecimentos "( Documento Magna Charta Universitatum).

Em setembro de 2008, na celebração do aniversário 920 da fundação da Universidade de Bolonha, o vigésimo da assinatura da Magna Charta Universitatum e os nove da Declaração de Bolonha, os reitores das universidades europeias reuniram-se para fazer balanços dos resultados alcançados até agora. A esta reunião foram convidados os reitores de instituições de ensino superior de países dos outros quatro continentes, incluindo América Latina. Um representante de cada região fez um relato dos principais benefícios que esta declaração trouxe para a Europa e ao resto do mundo. Representando a América Latina, o palestrante foi o químico Moisés Wasserman Lerner, ex-reitor da Universidade Nacional da Colômbia.

Por outro lado, do 5 até 9 de outubro de 1998 se reuniram na sede da UNESCO em Paris, importantes acadêmicos de todo o mundo participantes na Conferência Mundial sobre a Educação Superior, e aprovaram a Declaração Mundial sobre Educação Superior no século XXI: visão e ação; e o quadro de acção prioritária para a mudança e o desenvolvimento do ensino superior. O preâmbulo da declaração argumenta:

O ensino superior enfrenta-se em todos os lugares a desafios e dificuldades relacionados com o financiamento, a igualdade de condições de acesso aos estudos e durante o transcurso deles, uma melhor formação do pessoal, o treinamento baseado nas habilidades, a melhora e preservação da qualidade do ensino, a pesquisa e os serviços, a relevância dos currículos, a possibilidade de emprego dos graduados, o estabelecimento de acordos de cooperação eficientes e a igualdade de acesso aos benefícios que fornece a cooperação internacional. $O$ ensino superior deve enfrentar ao mesmo tempo os novos desafios que abrem as novas tecnologias, que melhoram a forma de produzir, organizar, divulgar e gerir o conhecimento e do acesso a o mesmo. Deverá garantir um acesso equitativo a essas tecnologias em todos os níveis dos sistemas de educação. (Declaração Mundial sobre Educação Superior no Século XXI) 
Ambos os documentos têm suscitado o início de um processo de reflexão sobre a qualidade do ensino universitário e a necessidade de grandes mudanças nos modos convencionais de ensino. Assim, os pesquisadores da Faculdade de Educação e Ciências Humanas da Universidade Militar Nueva Granada estão analisando um novo modelo pedagógico universitário chamado aprendizagem baseada em problemas (ABP), pois ele pode ajudar as instituições de ensino superior para enfrentar os desafios colocados pelo mundo globalizado (Felder e Brent, 2003).

A aprendizagem baseada em problemas (ABP) está emergindo como uma das abordagens pedagógicas mais inovadoras na formação profissional e acadêmica atual, conquistando cada vez mais espaço nas principais universidades do mundo, entre as quais se pode destacar a Universidade McMaster, em Canadá, a Universidade de Maastricht, na Holanda; da Universidade de Quebec, no Canadá; a Escola de Medicina, de Harvard; a Universidade Autônoma do México (UNAM); a Universidade de São Paulo, no Brasil. Esta abordagem pedagógica também chegou com força a Espanha liderado pela Universitat Autònoma de Barcelona, a Escola Universitária d'Infermeria Vall d'Hebron, a Universitat Pompeu Fabra, a Universidade Autónoma de Madrid e a Universidade de Valladolid.

Após esse movimento encontra-se a procura de novos modelos de produção e organização do conhecimento, de acordo com as demandas e necessidades das sociedades contemporâneas, bem como a denominada sociedade do conhecimento (Amaya, 2000; Van Berkel e Schmidt, 2001; Woods, 1996). A universidade tradicional, a qual segmentava o conhecimento em áreas, disciplinas e matérias, já não satisfaz as necessidades da adequação do conhecimento em novas redes e interfaces. Os estudos universitários exigem a elaboração depurada de sínteses complexas, com aportes de distintas fontes de informação para obter uma análise completa e desenvolvimento dos novos cursos e pesquisas científicas. Diante dessa perspectiva complexa e multifacetada e interdisciplinar, é claro que as mudanças são essenciais para fortalecer o papel da universidade na sociedade contemporânea e permitir a implementação das recomendações feitas pelos documentos internacionais e declarações sobre o ensino superior, e assim fortalecer esta tendência e trazer mudanças nos sistemas de ensino já instalados (Perkins, 1998).

Agora cabe às universidades latino-americanas pensar a Magna Charta Universitatum e a Declaração Mundial sobre a Educação Superior no Século XXI. Alguns reitores de universidades da América Latina e do Caribe que assinaram simbolicamente a Declaração de Bolonha (entre eles o reitor da nossa Universidade) se comprometeram a trabalhar fortemente na qualidade da educação que permita 
grande troca e fluidez, e que tenha uma forte presença internacional. Disso vai depender, em grande parte, como se pode evoluir no ensino superior.

O desafio não é fácil para estes países com altos níveis de pobreza e analfabetismo, especialmente com sistemas democráticos frágeis; no entanto, esperamos que, como resultado das declarações deste tipo de encontros se produzam ações ou políticas concretas que contribuíam para o progresso da instituição universitária e da educação, e não apenas que fique no entusiasmo passageiro dos participantes e a proclama de uma série de propósitos que desaparecem com a passagem do vento e do tempo.

A nossa contribuição para alcançar esta mudança educacional é propor a aprendizagem baseada em problemas como uma poderosa ferramenta educacional para a formação de profissionais, cientistas de nossas universidades da América Latina, em sociedades que exigem a estruturação de conhecimentos sólidos e profundos da realidade com vista para a inovação, a transformação da realidade e a construção da justiça social.

\section{Referências}

Amaya, A. (2000) La clase magistral, paradigma de una enseñanza eficaz. En: enseñabilidad de los saberes. Memorias sobre actualización y mejoramiento curricular. Bogotá: Editorial Universidad de la Sabana.

Cooney, T. (2002). Introduction. En J. Cusick (Ed.), Innovative Techniques for Large-Groups Instruction (pp. 135-145). Arlington: National Science Teachers Association

Declaración Mundial sobre la Educación Superior en el Siglo XXI: visión y acción. Recuperado el 28 de mayo de 2017, de http://www.unesco.org/education/educprog/ wche/declaration_spa.htm

Documento Magna Charta Universitatum (s. f.). Recuperado el 28 de mayo de 2017, de http://www.magna-charta.org/magna.htm

Felder, R.M. y Brent, R. (2003). Learning by Doing. Chemical Engineering Education, 37(4), 282-283.

Perkins, D. (1998). What is Understanding? En M.S. Wiske (Ed), Teaching for Understanding Linking Research with Practice. San Francisco: Jossey-Bass Publishers.

Van Berkel, H.J.M. y Schmidt, H.G. (2001). The Role of Lectures in Problem-Based Learning. Annual Meeting of the American Educational Research Association. Seattle.

Woods, D.R. (1996). Problem-Based Learning: Helping Your Students Gain the Most from PBL. Hamilton: Seldon Griffin Graphics. 